\title{
ИНСТИТУТ УГОЛОВНОЙ ОТВЕТСТВЕННОСТИ ЗА ПРЕСТУПЛЕНИЯ В СФЕРЕ АВТОРСКОГО ПРАВА В СОВЕТСКИЙ ПЕРИОД
}

\begin{abstract}
Аннотация: Предметом исследования являются уголовно правовые нормы и институты, предусматривающие ответственность за нарушение авторского права (интеллектуальной собственности), а также уголовное законодательство в период становления и развития советского государства (УК РСФСР 1922, 1926, 1960 гг.). Кроме того, в работе был проведен правовой анализ законодательных актов (декретов) съездов Советов, ВЦИК и СНК РСФСР принимавиихся в первые годы советской власти и регламентировавших и охранявших правоотношения в сфере авторских прав. Исследование проводилось на отраслевом уровне, историко-правовымметодом, с применением историко-ретроспективного подхода, позволяющего раскрывает суть и прогрессивность явлений прошлого с определенной исторической дистанци. Новизна исследования заключается в следующем: советское законодательство характеризуется идеологизированностью, не являлось исключением и законодательство об интеллектуальной собственности (авторское право). Отмена законодательства об авторском праве иарской России и формирование советского законодательства, а также введение уголовноправовой охраны интеллектуальной собственности, но уже с учетом государственной идеологии, тому является подтверждением. Таким образом исследование не подтверждает позици авторов о противоречивости законодательства как об интеллектуальной собственности, так и об его уголовной защите.В работе опровергается положение, согласно которому в период становления советского государства отсутствовала как таковая охрана авторских прав уголовно правовыми средствами. В указанный период времени защита авторских прав предусматривалась ст. 136 УК РСФСР 1922 г., т.е. специальной нормьл в уголовном законодательстве не существовало.
\end{abstract}

Ключевые слова: Авторское право, советская власть, УК РСФСР 19222., УК РСФСР 1926г., наказание, преступление, сословный характер, уголовная ответственность, Декрет, военный коммунизм.

Abstract: The subject of this research is the criminal legal norms and institutions that cover responsibility for violations of the copyright laws (intellectual property), as well as criminal legislation during the period of establishment and development of the Soviet state (Criminal Code of the Russian Soviet Federative Socialist Republic of 1922, 1926, and 1960). In addition to that, the author conducts a legal analysis of the legislative acts (decrees) of the congresses of the Councils of All-Russian Central Executive Committee, and the Council of People's Commissars of the Russian Soviet Federative Socialist Republic passed during the first years of the Soviet power, and regulations and maintaining legal relations in the area of copyright. The novelty of this research consists in the following: Soviet legislation, including the legislation on intellectual rights is characterized as ideological; the annulment of the legislation on copyright of the Russian Empire and formation of the Soviet legislation, including introduction of criminal legal protection of intellectual property, but with consideration of state ideology, serves as a proof to that regard. Thus, the research does not confirm the positions of the authors on the contradiction of legislation on both, intellectual property, as well as its criminal protection.

Keywords: Copyright, Soviet era, Intellectual property, CC RSFSR, Crime, Punishment, Social categories, Criminal responsibility, Decree, Military communism.

нститут уголовной ответственности за преступления посягающие на авторские и смежные права в России имеет длительную историю. Как известно он появился в 1832 г., несколько позже чем сам институт авторского права. За все время существования этот институт претерпевал изменения под воздействием социально-экономических преобразований происходивших в Российском государстве в разные периоды его исторического развития.

Тема рассматриваемого института исследовалась в диссертационных работах Б.В. Здравомыслова ${ }^{[17]}$, С.Н. Титова ${ }^{[50 . c . ~}{ }^{21-26]}$, Т.Н. Лепиной[28. с. ${ }^{51-58]}$, 
DOI: $10.7256 / 1811-9018.2015 .8 .15784$

При цитировании этой статьи сноска на доі обязательна

\section{Право и политика 8 (188) 2015}

В.А. Кондрашиной ${ }^{[24 \text { с. 149-158], Е.Н. Демьяненко }}{ }^{[10 . ~ c . ~ 20-34], ~}$ В.Н. Бондарев ${ }^{[3]}$ и др. Эти авторы внесли определенный вклад в теорию уголовного права по этой проблеме, вместе с тем некоторые ее аспекты не нашли единообразного понимания. Например, в науке уголовного права существует позиция согласно которой в первые годы советской власти в советском государстве, почти была устранена охрана интеллектуальной собственности $^{[51 . c .21]}$, есть и такая точка зрения, что УК РСФСР 1922 г., не предусматривал уголовно-правовую охрану прав авторов. Вместе с тем Б.В. Здравомыслов придерживался иной точки зрения. Кроме того анализ научной литературы показал, что в теории уголовного права рассматриваемой теме посвящено не так много работ. При ее изучении автору встретились отдельные современные работы критически анализирующие ситуацию, сложившуюся в сфере уголовно правовой защиты результатов интеллектуальной деятельности, их авторы отталкивались в первую очередь от идеологии главенствующей в стране. Либо работы в которых этому институт в рассматриваемый период уделено на наш взгляд недостаточно внимания. Представляется, этот период истории его развития интересен хотя бы потому, что он существовал и развивался в период бытия первого в мире советского государства. В этой связи интересен вопрос о решении проблем стоящих перед учеными и законодателем в Царской России об уголовно правовом обеспечении защиты интеллектуальной собственности, в СССР. Например о месте уголовных запретов посягающих на результаты интеллектуальной деятельности в Особенной части УК РСФСР; о конструкции составов преступлений.

В рамках исследования автор считал бы возможным проследить становление и развитие института уголовной ответственности за преступления в сфере авторского права в советский период на основе анализа уголовного законодательства, нормативно-правовых источников, регламентирующих охранительные правоотношения в сфере авторских прав, законодательства об авторском праве, с целью уяснения оценки уголовно-правовой охраны авторского права в рассматриваемый период.

Полагаем необходимо отметить, по какой причине при исследовании института уголовной ответственности за нарушение авторских прав анализируется и законодательство об авторском праве. Это вызвано тем, что данные о предмете преступления имеют криминалистическое значение и являются непременным условием для правильной оценки происшедшего события (преступления).
Известно, последним законом в области интеллектуальной собственности в Российской Империи стало положение (Закон) об авторском праве от 20 марта 1911 г., вобравшее в себя передовые взгляды того времени на интеллектуальную собственность автору произведения принадлежало исключительное право всеми способами воспроизводить, опубликовывать и распространять свое произведение (ст. 2), исключительное право понималось как имущественное право. В законе были размещены и нормы предусматривающие уголовную ответственность за посягательства на авторские права ст. 620, 622 ${ }^{[18 . c .4]}$.

Таким образом, к концу XIX-начало XX в. в России сформировалось законодательство, регулирующее и осуществляющее уголовную охрану интеллектуальной собственности (авторских прав), хотя и не решало всех проблем возникающих в сфере охраны исключительных прав авторов.

После совершения революции 1917 г. и установления советской власти начались серьезные преобразования в политической, экономической и культурной сферах, изменилось и правовое положение авторов.

Законодательство России Империи ${ }^{[11]}$, было упразднено $^{[37]}$ («в части, противоречащей декретам ЦИК Советов Р., С. И Кр. Деп. И Рабочее Крестьянского правительства...») начался процесс построения нового законодательства с учетом социалистической идеологии, обусловившей новый взгляд на интеллектуальную собственность и необходимости ее защиты.

Первым нормативным актом по авторскому праву был Декрет ВЦИК «О государственном издательстве» ${ }^{[12]}$ от 29 декабря 1917 г., который поручал Государственной комиссии по просвещению организовать широкую издательскую деятельность произведений русских классиков. В развитии этого декрета проводится монополизация сочинений некоторых авторов, срок авторских прав на которые уже истек. Особым постановлением Государственной комиссии по просвящению объявлялась монополия государства на такие произведения сроком не более чем на пять лет. Таким образом, права авторов, возникшие до революции, полностью сохранялись. «Именно поэтому декрет предлагал монополизировать и переиздать сочинения только тех классиков, срок авторского права которых истек»[2. с. 44].

Издание и распространение не национализированных произведений производилось только с разрешения автора или его наследников.

В этой связи нельзя согласиться с точкой зрения о том $^{[30 . \text { c. 53] }}$, что государство этим декретом монополизировало сочинение всех авторов. 
Несколько позднее Декретом СНК от 26 ноября 1918 г. «О признании научных, литературных, музыкальных и художественных произведений государственным достоянием» были национализированы авторские права на «всякое как опубликованное, так и неопубликованное научное, литературное, художественное произведение, в чьих бы руках оно ни находилось...» (ст. 1 декрета $)^{[13]}$. Достоянием республики могли быть объявлены все произведения любого умершего автор.

При этом необходимо отметить следующее, монополизируемые произведения должны отвечать определенным требованиям, а именно должны были быть близки «по духу» трудовому народу. «что являлось важным ориентиром не только для издателя, но и для авторской деятельности».

Декрет установил право автора на созданное им произведение, и не на объявленное государственным достоянием (ст. 3-4), запретив всякое нарушение авторского права (контрафакцию), которая влекла за собой ответственность, как за нарушение государственной монополии (ст.11). Лиц, занимающихся контрафакцией, в том числе и произведений, не объявленных государственным достоянием, в советском государстве считали опасными для правопорядка. Ведь речь шла о пресечении частных предпринимателей обогатиться за счет нарушения авторских прав охраняемых государством.

Кроме того декрет урегулировал вопрос о вознаграждении авторов (ст.5).

Декрет от 27 апреля 1918 «Об отмене наследования» ${ }^{[20]}$ решил отрицательно вопрос наследования авторского права на произведения.

Декретом ${ }^{[38]}$ СНК РСФСР от 30 июня 1919 г. «Об изобретениях» (Положение) отменялись все законы и положения о привилегиях на изобретения, изданные до опубликования декрета (п.10), патентная система охраны изобретений была ликвидирована. Государство наделялось правом «всякое изобретение, признанное полезным Комитетом по делам изобретений, могло объявлять достоянием Р.С.Ф.С.Р.» (п.1).

В инструкции к Декрету СНК от 1919 г. «Положение об изобретениях» ${ }^{[21]}$ была установлена явочная система охраны промышленных образцов ${ }^{[39]}$.

Таким образом, преобразования, проведенные в первые годы советской власти, в области авторских прав, несомненно, привели к их значительному ограничению, внедрялся принцип приоритета общественного интереса над частным. Более того, современники (С.И. Раевич $\left.{ }^{[36 . \text { с. } 30 \text { и 34] }, ~ И . Я . ~ Х е и ̆ ф е ц ~}{ }^{[52 . \text { с. 4] }, ~ П . ~ С т у ч к а ~}{ }^{[53]}\right)$ вообще считали, что «декрет от 26 ноября 1918 г., отменил в общем порядке дореволюционное положение 1911 г., и оставил Россию без авторского права, которое было в принципе экспроприировано» ${ }^{[15]}$.

Вместе с тем есть и другая точка зрения. Так, В.И. Корецкий пишет, что в первые годы законодательство советского государства было нацелено на ликвидацию всех форм эксплуатации авторов издателями и другими предпринимателями. На их место приходили государственные организации и предприятия и в меньшей степени кооперативы и иные общественные организации. Однако дореволюционное авторское право в рассматриваемый период «полностью ликвидировано не было. Его отдельные нормы применялись в 1917 и 1918 годах, для регулирования авторских отношений в той мере, в которой эти отношения еще не были урегулированы

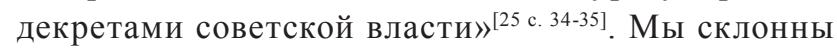
придерживаться точки зрения В.И. Корецкого, на том основании, что она находит свое подтверждение при анализе декретов. Правовая охрана авторских прав в этот период, на наш взгляд имела место (ст. 3, 4 и 11 декрета СНК от 26 ноября 1918 г.).

В период новой экономической политики ситуация с правами авторов претерпевает изменения. В советской правовой системе вновь появилось право автора на результаты интеллектуальной деятельности. Так в сентябре 1924 г., ЦИК и СНК РСФСР было принято постановление «О патентах на изобретения», патент стал вновь формой охраны изобретательских прав (п. 14), он мог передаваться третьим лицам и переходить по наследству (п. 10). Постановление предоставляло патентообладателю исключительное право осуществлять принадлежащее ему изобретение в виде промысла (п. 9).

Вместе с тем, в отдельных случаях государство оставляло за собой право принудительно отчуждать патент в свою пользу при отсутствии добровольного соглашения со стороны патентообладателя (п. 15). Налицо приоритет общественного интереса над частным.

Одновременно с Постановлением о патентах на изобретения ЦИК и СНК СССР 12 сентября 1924 г. принимают Постановление «О промышленных образцах (рисунках и моделях)» ${ }^{[40]}$. Согласно п. 7 указанного Постановления лицу зарегистрировавшему образец, предоставлялось исключительное право пользования им (образцом), воспроизводить в пределах Союза ССР этот образец в целом или в отдельных характерных частях, вводить изделия, воспроизводящие образец, в оборот или иным образом пользоваться ими.

Уголовный кодекс РСФСР ${ }^{[41]} 1922$ г. (далее - Кодекс) устанавливал ответственность за нарушение авторских прав на промышленную собственность (ст. 198-199), 
DOI: $10.7256 / 1811-9018.2015 .8 .15784$

При цитировании этой статьи сноска на доі обязательна

\section{Право и политика 8 (188) • 2015}

которые располагались в главе VI «Имущественные преступления» Особенной части. Так ст. 198 Кодекса за «самовольное пользование из корыстных мотивов чужим изобретением или, привилегией, зарегистрированными в установленном порядке» влекло наказание «принудительными работами на срок до одного года или штрафом в тройном размере против полученного от самовольного использования прибыли».

Согласно ст. 199 «самовольное пользование в целях недобросовестной конкуренции чужим товарным, фабричным или ремесленным знаком, рисунком, моделью, а равно и чужой фирмой или чужим наименованием» наказывалось «принудительными работами на срок до одного года или штрафом в тройном размере против извлеченной от самовольного пользования выгоды».

Рассматриваемый Кодекс предусматривал уголовную ответственность и за самовольное издание, размножение с целью сбыта литературных, музыкальных и вообще художественных произведений, признанных только достоянием республики (ст. 101). Каралось такое деяние принудительными работами на срок до одного года с конфискацией имущества или без такового. Уголовно правовая норма находилась в гл. I «Государственные преступления» отд. II «О преступлениях против порядка управления». Такое расположение нормы в Особенной части Кодекса у исследователей ${ }^{[16 .}$ c. 58] вызывало и вызывает критику. В дальнейшем в уголовном праве, как советского периода, так и России объектом нарушения авторских прав не был порядок управления. На наш взгляд, в период становления советского государства такое расположение этой нормы, да впрочем и других норм, объектом которых также не является порядок управления, вполне закономерно. Оно (расположение) продиктовано желанием государства защитить порядок управления в нем, усилить авторитет власти (ст. 74 УК РСФСР).

В научной литературе отмечается, что в первые годы существования советского государства почти полностью отсутствовала правовая охрана интеллектуальной собственности (авторских прав) ${ }^{[29 . c . ~ 54]}$. Отчасти с такой позицией можно согласиться. От термина интеллектуальная собственность в советском государстве, в первые его годы, отказались. Однако, на наш взгляд, даже с учетом очень значительного сокращения авторских прав, чьи произведения были монополизированы государством правовая охрана прав авторов, произведения которых монополизированы не были, существовала. Так, согласно п. 11 Декрета СНК РСФСР от 26 ноября 1918 «О признании научных, литературных, музыкальных и художественных произведений государственным достоянием» за «самовольное издание, размножение, распространение и публичное исполнение произведений, вопреки постановлению настоящего декрета», ${ }^{[14]}$ влекло уголовную ответственность, «как за нарушение государственной монополии». Рассматриваемая норма охватывала, в том числе и положения регулирующие отношения автора чье произведение не было монополизировано государством с другими лицами (п.3). При этом ст. 136 УК РСФСР 1922 г., предусматривала ответственность в виде принудительных работ или лишение свободы на срок не ниже шести месяцев, за «нарушение положений, регулирующих проведение в жизнь государственных монополий».

В этой связи необходимо отметить, что советское уголовное законодательство первой половины XX в., не содержало специальных норм устанавливающих ответственность за самовольное издание, размножение, распространение и публичное исполнение произведений. Ответственность за данные деяния наступала по указанной выше статье. Такая ситуация, например, была и с преступлениями, посягающими на охрану монополии государственной собственности на землю.[1.]

С развитием новой экономической политики все более расширялись права граждан на объекты интеллектуальной собственности. Постановление ЦИК и СНК СССР от 30 января 1925 г. «Об основах авторского права» ${ }^{[42]}$ и Декрет ВЦИК и СНК РСФСР от 11 октября 1926 г. «Об авторском праве» ${ }^{[22]}$ предусматривали исключительное право автора на выпуск в свет, воспроизведение и распространение своего произведения, а равно извлекать всеми законными способами имущественные выгоды из своего исключительного права (п. 3 Постановления). Однако, допускался принудительный выкуп любого произведения (п. 15 Закона).

По существу советское законодательство охраны авторских прав, в периода нэпа это - постепенное восстановление и расширение охраны авторских прав. Направлено оно было в основном на защиту имущественного интереса авторов. «В соответствии с законом «Об авторсокм праве» признавались исключительные личные и имущественные права за всеми авторами в течении всей жизни и 15 лет после его смерти. Использование произведений иными лицами должно было осуществляться на основании соответствующего договора. Однако, советское законодательство содержало и широкий перечень изьятий из авторского права» ${ }^{[49]}$. Например, допускалось без разрешения автора публичное исполнение опубликованных произведений. Вместе с тем, п. 11 постановления ЦИК и СНК СССР от 30 января 1925 г. «Об основах авторского права» 
предписывает защищать авторские права и в тех случаях когда с нарушением его не связаны определенные имущественные интересы.

Однако в дальнейшем, как отмечают многие исследователи с «планово-командной системой в экономике нашей страны, роль рыночных рычагов, включая право на результаты интеллектуальной деятельности, резко снизилась, исключительные права авторов были сведе-

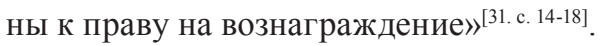

Расширение авторских прав в указанный период времени получили и изобретатели. Постановлением ЦИК СССР от 9 апреля 1931 г. № 3/2 $2^{[44]}$ было утверждено Положение об изобретениях и технических усовершенствованиях. Согласно п. «а» и «б» ч. 2 Постановления, автору изобретения предоставлялся выбор требовать признания только его авторства и соответственно будет выдано авторское свидетельство, либо ему будет предоставлено исключительное право на изобретение с последующей выдачей патента.

С действием в советском государстве новой экономической политики и предоставлением его гражданам права создавать промышленные и торговые предприятия произошло возрождение на некоторое время понятия предприятия (фирмы) в российском законодательстве. В 1927 г., было принято постановлением ЦИК и СНК СССР «Положения о фирме» ${ }^{[45]}$, в котором раскрывалось понятие фирмы и определялось содержание права на нее. ${ }^{[6]}$

В результате индустриализации в стране в 30 -х года сложилась экономическая ситуация (поднялся уровень производства, у граждан появилась возможность выбора продукции хорошо зарекомендовавших себя предприятий), потребовавшая приведения законодательства о товарных знаках в соответствие с изменившимися условиями. В марте 1936 г. ЦИК и СНК СССР принимают Постановление «О производственных марках и товарных знаках» ${ }^{[46]}$ согласно, которому вводилась новая разновидность товарного знака-торговая марка (торговый знак).

Тенденция приоритета охраны исключительных прав авторов нашла свое отражение и в УК РСФСР 1926 года.

Принятом в период нэпа уголовном законе, статья 177 предусматривающая ответственность за «самовольное пользование изобретением с нарушением правил, установленных в законах о патентах на изобретения, а равно самовольное использование литературных, музыкальных и иных художественных или научных произведений с нарушением закона об авторском праве», также как и ст. 178 этого Закона, предусматривающая ответственность за «самовольное пользование в целях не добросовестной конкуренции чужим товарным, фабричным или ремесленным знаком, рисунком, моделью, а равно и чужой фирмой или чужим наименованием», были помещены в главу VII «Имущественные преступления». При этом следует отметить, что УК РСФСР в редакции 1926 г., «в ст. 178 сохранил уголовную ответственность за те же формы недобросовестной конкуренции, что и в УК РСФСР 1922 года» ${ }^{[32]}$. Кроме того, как видно в новой редакции Закона санкции были смягчены. Срок принудительных работ снижен с одного года до шести месяцев, «а вместо «оборотных» штрафов был установлен штраф не в процентом, а натуральном показателе до трех тысячь рублей»» ${ }^{[3 . c . ~ 34] ~ В ~ У К ~ Р С Ф С Р ~}$ 1926 г. по сравнению с УК РСФСР в редакции 1922 года, был расширен перечень объектов интеллектуальной собственности, подлежащей уголовно -правовой охране: «изобретение», «научное произведение».

Деяние, предусматривавшее наказание за «самовольное издание, размножение с целью сбыта литературных, музыкальных и вообще художественных произведений, признанных достоянием республики» (ст. 101 УК РСФСР 1922 г.) было декриминализировано.

Очередным этапом в развитии авторского права и его уголовно-правовой охраны можно назвать средину 50-х и начало 60-х годов ХХ в. В этот период разрабатываются и принимаются Основы гражданского законодательства Союза ССР и союзных республик - 1961 ${ }^{[7]}$ г., (далее -Основы) в который нормы об авторском праве, были включены в качестве отдельных разделов. Например, раздел IV регулировал авторские права в сфере произведения науки, литературы или искусства; раздел V-право на открытие; раздел VI право на изобретение, рационализаторское предложение и промышленный образец. Однако, как показывает исследование нормативных актов советского периода и научной литературы в рассматриваемой сфере, «... положения о товарных знаках (равно как и о других средствах индивидуализации) не вошли ни в Основы 1961 г., ни в ГК РСФСР 1964 г. (в отличие от норм, посвященных авторскому и патентному праву). Тем самым законодательство о товарных знаках перешло в сферу интересов узких специалистов» ${ }^{[34]}$. В это время права авторов были закреплены в таких нормативных актах как: Постановление Совета Министров СССР от 15.05. 1962 «О товарных знаках» ${ }^{[47]}$ и утвержденные на его основе Положение о товарных знаках 1974 г. ${ }^{[4]}$ СССР в этот период присоединяется к ряду международных конвенций таких как: ВОИС $1967 \Gamma^{[26]}$., Всемирной Конвенции об авторском праве 1952 г. ${ }^{[48]}$; Ниццкое Соглашению о 
DOI: $10.7256 / 1811-9018.2015 .8 .15784$

При цитировании этой статьи сноска на доі обязательна

\section{Право и политика $8(188) \cdot 2015$}

международной классификации товаров и услуг для регистрации знаков 1957 г. ${ }^{[35]}$; Парижской конвенции по охране промышленной собственности 1883 г. $^{[19]}$

Кроме того, авторские права больше не именовались исключительными. «Категория исключительного права вновь была введена в отечественное законодательство лишь в 1991 г., когда были приняты Основы гражданского законодательства Союза ССР и республик (п. 2 ст. 135)» ${ }^{[27]}$.

Принятый в 1960 г. новый УК РСФСР ${ }^{[8]}$ не предусматривал ответственность за использование чужого фирменного наименования. Уголовное законодательство этого периода охватывало охрану только обьектов таких авторских прав, как научное, литературное, музыкальное или художественное произведение, а также изобретение, рационализаторское предложение и товарный знак. Также необходимо отметить, что впервые в советском уголовном законодательстве устанавливалась ответственность за принуждение к соавторству. Признак преступления «принуждение» в УК РСФСР 1960 г., был впервые использован для законодательного описания способа совершения преступления.

Так, ст. 141 УК РСФСР предусматривала ответственность за «выпуск под своим именем чужого научного, литературного, музыкального или художественного произведения или иное присвоение авторства на такое произведение либо незаконное воспроизведение или распространение такого произведения, а равно принуждение к соавторству» в виде «исправительных работ на срок до двух лет или штрафа до трех минимальных месячных размеров оплаты труда»;

наступала ответственность за «оглашение изобретения до заявки без согласия изобретателя, присвоение авторства изобретения, принуждение к соавторству на изобретение, а равно присвоение авторства на рационализаторское предложение»; эти действия влекли наказание «исправительными работами на срок до двух лет или штрафом до трех минимальных месячных размеров оплаты труда».

В научно правовой литературе есть мнение, согласно которому в уголовных законах предшествующих УК РФ 1996 г., ответственность за совершение плагиата предусматривала наиболее строгие санкции по сравнению с другими посягательствами на авторские и смежные права. И что на всем протяжении истории уголовной охраны интеллектуальной собственности в России наблюдалась тенденция к смягчению наказания. Следующим шагом законодателя, по мнению автора должна быть декрминализация плагиата. (Лепина Т.Н. Уголовно-правовая охрана интеллектуальной собственности: дисс. ... канд. юрид. наук. Курск, 2014. С. 61).

С позицией автора можно согласиться в той части, что к концу XIX в., в Царской России за рассматриваемое преступление законодатель смягчил наказание, как в общем и за все посягательства на авторские права. Ответственность за плагиат, в СССР была предусмотрена ст. 141 УК РСФСР 1960 г., исследования показывают, что вид и размер наказания за это преступление почти не имел различий от вида и размера наказания за иные преступления против авторских и смежных прав. Например, ч. 1 ст. 141 УК РСФСР 1960 г., за «выпуск под своим именем чужого научного, литературного, музыкального или художественного произведения или иное присвоение авторства» предусматривала ответственность в виде исправительных работ на срок до двух лет или штраф до трех минимальных месячных размеров оплаты труда. За незаконное пользование чужим товарным знаком наказание исправительные работы на срок до двух лет или штраф до трех минимальных месячных размеров оплаты труда (ст. 155 УК РСФСР 1960 г.). Как видно из приведенного примера позиция автора не находит подтверждение.

Вопрос декриминализации преступления присвоение авторства (плагиат), это проблема, и на наш взгляд, вряд ли может зависеть от исторических тенденций в праве. Известно, что процесс декриминализации происходит в том случае, когда деяние признанное ранее общественно опасным перестает быть таковым.

Вместе с тем, автор согласен с вышеприведенной позицией в части декриминализации плагиата. Представляется, что повышенная общественная опасность этого деяния под вопросом. К уголовной ответственности за плагиат лица привлекаются крайне редко, можно сказать, что норма практически не работающая. В свою очередь гражданско-правовые меры, и меры административной ответственности на наш взгляд являются эффективными.

Рассматриваемый Закон в отличии от предыдущего УК РСФСР 1926 г., предусматривал ответственность за оглашение изобретения до заявки без согласия изобретателя (т.е. сообщение другим лицам идеи изобретения или основных технических средств ее реализации). Кроме того, введена норма, запрещающая под угрозой наказания присвоение авторства на рационализаторское предложение.

Уголовный кодекс 1960 г., в отличие от УК РСФСР 1922 и 1926 годов не содержал нормы, предусматривающие ответственность за самовольное пользование чужим фабричным или ремесленным знаком, рисунком, моделью, 
аравно чужой фирмой или чужим наименованием. Вместе с тем, нельзя сказать, что Кодекс не предусматривал ответственность за интеллектуальную собственность в сфере промышленной собственности. УК РСФСР 1960 г. содержал ст. 155, предусматривающую ответственность за незаконное пользование товарными знаками. Согласно этой статье незаконное пользование товарным знаком наказывалось исправительными работами на срок до шести месяцев или штрафом до трехсот рублей. При этом в отличие от ст. 178 УК РСФСР 1926 г. в ст. 155 УК РСФСР отсутствовало указание на цель деяния.

Указанные уголовно-правовые запреты законодателем были помещены в главу 4 «Преступления против политических и трудовых прав граждан» (ст. 141), и в главу 5 «Хозяйственные преступления» (ст. 155 УК РСФСР).

Такие образом, как показывает анализ уголовного законодательства советского периода в этой сфере, важнейшей его задачей являлось прежде всего охрана интересов государства и общества и лишь затем интересов личности в этой области.

В целом общие принципы охраны авторских прав в СССР во второй половине XX в., при всех ограничениях этих прав, на наш взгляд соответствовал нормам большинства зарубежных стран. Исследователи того времени отмечали, в частности В.М. Гордон, что «... в СССР построена такая система отношений, которая не только гарантирует соблюдение... прав авторов, но вместе с тем позволяет строить данные отношения так, чтобы не противопоставлять интересы авторов и интересы общества» ${ }^{[43]}$.

Вместе с тем полагаем, что в России традиционно низкий уровень охраны авторских прав. Это обусловлено следующими обстоятельствами, изолированностью от внешнего мира, не участие России продолжительное время ни в одном из важнейших международных соглашений по охране авторского права и др.

Преобразование в политике и экономики, происходившие в России в 1990-х гг., обусловили и реформирование законодательства, непосредственным образом касающееся авторского права и его уголовно-правовой охраны.

В 1993 г. был принят Закон «Об авторском праве и смежных правах». С принятием этого нормативного акта правовое регулирование охраны обьектов авторского права в России стало намного ближе к европейским стандартам в этой сфере и уровню охраны авторских прав в большинстве развитых стран ${ }^{[23]}$. Годом ранее был принят Патентный закон и ряд других.

Другим значительным шагом к совершенствованию российского авторского законодательства стало присо- единение России в 1995 г. к Бернской конвенции об охране литературных и художественных произведений ${ }^{[5]}$ (с оговоркой Россия «не взяла на себя бремя охраны на своей территории старых иностранных произведений, которые ранее не пользовались правовой охраной» ${ }^{[9]}$ на ее территории), а также к Всемирной конвенции об авторском праве.

В этом же году появился первый отдельный состав административного правонарушения в этой сфере, (ст. 150.4 КоАП РФ) (Продажа, сдача в прокат и иное незаконное использование экземпляров произведений или фонограмм).

В 1997 г. в России вступил в действие УК РФ, в который вошли статьи, предусматривающие ответственность за нарушение авторских и смежных прав (ст. 146 УК РФ) и изобретательских и патентных прав (ст. 147 УК РФ). Предусмотрена ответственность и за незаконное использование средств индивидуализации товаров (работ, услуг) (ст. 180 УК РФ).

За последние 18 лет российское уголовное законодательство в сфере защиты интеллектуальной собственности претерпело определенные изменения. Так, в 2003 г., в соответствии с Федеральным законом от 08 декабря 2003 № 162-Ф3 было произведено разграничение ответственности за преступления против имущественных и неимущественных прав авторов (изменилась мера наказания за совершение плагиата, в настоящее время исключено наказание в виде лишения свободы); указан признак субьективной стороны - цель сбыта контрафактной продукции; заменен оценочный признак «крупный ущерб» на признак «совершение преступления в крупном размере»; преступление, предусмотренное ч. 2 ст. 146 переведено в разряд публичных; исключен признак неоднократности.

Федеральным законом от 27. 07. 2006 № 153-Ф3 за квалифицированное совершение преступлений, предусмотренных ч. 3 ст. 146 УК РФ увеличен срок наказания в виде лишения свободы до шести лет, следовательно, эти преступления перешли в категорию тяжких преступлений.

Позже в указанные нормы вносились и другие изменения и дополнения, о которых речь пойдет в отдельной работе.

Структурно нормы расположены в разных главах УК РФ - ст. 180 в гл. 22 «Преступления в сфере экономической деятельности», ст. 146 и 147 в гл. 19 «Преступления против конституционных прав и свобод человека и гражданина».

Исследование показывает с точки зрения систематизации уголовно правовых запретов в России 
DOI: $10.7256 / 1811-9018.2015 .8 .15784$

При цитировании этой статьи сноска на dоі обязательна

\section{Право и политика 8 (188) • 2015}

современной, а также дореволюционной и советский периоды, отсутствует системный подход к обеспечению охраны интеллектуальной собственности и восприятие последней как единого объекта, за исключением положения об авторском праве Российской империи от 20 марта 1911 г.

Известно, что интеллектуальная собственность имеет особенности своей природы, а потому на наш взгляд нуждается в отдельном правовом регулировании.

Одной из причин плохого выявления правоохранительными органами преступлений посягающих на интеллектуальную собственность, кроется в проблеме установления ущерба причиненного автору, проведенное исследование показало, что уголовно правовые нормы предусматривающие ответственность за посягательства на авторские права в СССР по конструкции были формальными, действующие нормы по конструкции являются материальными, за исключением (ч. 3 ст. 146, 180 УК РФ и ч. 2 ст. 147 УК РФ). Представляется, что существенным шагом для устранения этой проблемы может быть изменения конструкций составов преступлений на формальные.
В советский период законодательство об интеллектуальной собственности (авторское право), как впрочем, и все законодательство, характеризуется крайней идеологизированностью. Отмена законодательства об авторском праве царской России затем его постепенное восстановление, а также введение уголовно-правовой охраны интеллектуальной собственности, но уже с учетом государственной идеологии, тому является подтверждением.

В последующем по мере развития производства, торговли и присоединения государства к международным соглашениями в рассматриваемой сфере права авторов и изобретателей постепенно расширялись, подвергалось изменению и уголовное законодательство.

Нормы, предусматривающие уголовную ответственность на результаты интеллектуальной деятельности не были структурированы в отдельной главе УК РСФСР или как в царской России (положение об авторском праве от 1911 года.). Полагаем, это говорит о том, что законодатель и в дореволюционный и советский периоды интеллектуальную собственность не воспринимали как единый объект.

\section{Библиография:}

1. Алексеенко Н.Н. Уголовно-правовая и криминологическая характеристика преступлений в сфере регистрации незаконных сделок с землей. Монография. «Юрист», 2013. 151 с.;

2. Антимонов Б.С., Флейшиц Е.А. Авторское право Москва. Госюриздат, 1957-278 с.

3. Бондарев В.Н. Уголовно-правовая охрана интеллектуальной собственности: дис. ... канд. юрид. наук. Ростов - на-Дону, 2002. C. 24-31. 227 c.

4. «Бюллетень нормативных актов министерств и ведомств СССР», № 1, 1988.

5. «Бюллетень международных договоров», № 9, 2003.;

6. Венедиктов Ю.С. Проблемы фирменных наименований юридических лиц в историко-правовом контексте. Юридический мир, 2011, № 11.;

7. Ведомости ВС СССР, 1961. № 50. Ст. 525.;

8. «Ведомости ВС РСФСР», 1960, № 40, ст. 591.;

9. Гаврилов К.М. Что следует из Постановления Правительства РФ от 11.12.2012 № 1281 «Патенты и лицензии», 2013, № 4.;

10. Демьяненко Е.В. Уголовная ответственность за незаконное использование товарного знака: дис. ... канд. юрид. наук. Ростов на Дону, 2003. С. 20-34.216 с.

11. Декрет от 24 ноября 1917 СНК «О суде» // «Газета Временного Рабочего и Крестьянского Правительства», № 17, 24.11 .1917 г.

12. Декрет «О государственном издательстве» от 29 декабря 1917 г. // «Газета Временного Рабочего и Крестьянского Правительства», № 2, 04.01.1918.

13. Декрет СНК от 26 ноября 1918 г. «О признании научных, литературных, музыкальных и художественных произведений государственным достоянием» // Известия ВЦИК. № 263. 01.12.1918.

14. Декрет ВЦИК от 29.12.1917 г. «О государственном издательстве»; Декрет СНК РСФСР от 26.11. 1918 г. «О признании научных, литературных, музыкальных и художественных произведений государственным достоянием» и Декрет СНК РСФСР от 26. 10. 1919 г. «О прекращении силы договоров на приобретение в полную собственность произведений литературы и искусства», утратили силу со дня вступления в действие Декрета СНК РСФСР от 12.04. 1926 г. «Об утверждении перечня узаконений РСФСР, утративших силу с изданием постановления ЦИК и СНК Союза СССР от 30.01 .1926 г., «Об основах авторского права». // «Известия ЦИК СССР и ВЦИК», № 94, 24.04.1926.;

15. Е. Лозман Об авторском праве. Еженедельник Советской юстиции. 1923. № 1

16. Жижиленко А.А. Преступления против имущества и исключительных прав. Л., 1928. С. 58.;

17. Здравомыслов Б.В. Уголовно-правовая охрана прав автора и изобретателя в СССР// ВЮЗИ. 1957.

18. Займовский С.Г. Авторское право. Из-ние 2. М., 1914. С. 4.124 с.

19. «Закон», № 7, 1999 (извлечение); 
DOI: $10.7256 / 1811-9018.2015 .8 .15784$

При цитировании этой статьи сноска на dоі обязательна

История государства и права

20. «Известия ВЦИК», № 87, 01.05.1918.

21. «Известия ВЦИК», № 144. 04.07.1919.;

22. «Известия ЦИК СССР и ВЦИК» № 256, 05.11.1926;

23. Известно, Закон об авторском праве был разработан с учетом положений Типового закона ВОИС об авторском праве, при подготовке которого учитывались опыт регулирования авторских отношений в развитых странах и требований международных соглашений;

24. Кондрашина В.А. Уголовная ответственность за незаконное использование товарного знака по законодательству России и зарубежных стран: дис. ... канд. юрид. наук. Казань, 2004. С. 149-158. 229 с.

25. Корецкий В.И. Авторские правоотношения в СССР. Сталинабад. 1959. С. 34-35.

26. Конвенция ратифицирована Указом Президиума ВС СССР от 19.09.1968 № 3104-VII. Вступил в силу для России с 26 апреля 1970 г.;

27. Котенко Е.С. «Авторские права на мультимедийный продукт: Монография» «Проспект», 2013;

28. Лепина Т.Н. Уголовно-правовая охрана интеллектуальной собственности: дисс. ... канд. юрид. наук. Курск, 2014. C. $51-58.235$ c.

29. Лепина Т.Н. Указанная работа. С. 54. 235 с.

30. Лепина Т.Н. Указанная работа. С. 53.

31. Право интеллектуальной собственности: учебник / под ред. И.А. Близнеца. М., 2010. С. 14 -18.;

32. Писенко К.А., Бадмаев Б.Г., Казарян К.В. Антимонопольное (конкурентное) право. Подготовлено для системы КонсультантПлюс, 2014;

33. Писенко К.А., Бадмаев Б.Г., Казарян К.В. Указанная работа. С. 34.;

34. «Практика рассмотрения коммерческих споров: Анализ и комментарии постановлений Пленума и обзоров Президиума Высшего Арбитражного Суда Российской Федерации» выпуск 17, (под ред. Л.А. Новоселовой, М.А. Рожковой) «Статут», 2011.;

35. Публикация ВОИС, № 292(R), 1992.;

36. Раевич С.И. Интеллектуальные права. 1926. С. 30 и 34 (сноска).

37. Руководящие начала по Уголовному праву РСФСР. Приняты Постановлением НКЮ 12 декабря 1919 г.// СУ РСФСР, 1919, № 66 ст. 590 .

38. Собрание узаконений РСФСР. 1918. № 14. Ст. 201.

39. Судариков С.А. «Право интеллектуальной собственности: Учебник» «Проспект», 2010;

40. «СЗ СССР». 1924. № 9. ст. 98.

41. «СУ РСФСР», 1922, № 15, ст. 153;

42. СУ РСФСР. 1926. № 72. Ст. 576.;

43. Ситдиков Р.И. Обеспечение частных, общественных и публичных интересов авторским правом. «Статут» 2013.;

44. «СЗ СССР», 1931, № 21, ст. 181.;

45. «С3 СССР», 1927, № 40. Ст. 395.;

46. «С3 СССР», 1936, № 13, ст. 113.;

47. «СП СССР», 1962, № 7, ст. 59;

48. «СП СССР», 1973, № 24, ст. 139.;

49. Ситдикова Р.И. Обеспечение частных, общественных и публичных интересов авторским правом. «Статут», 2013.;

50. Титов С.Н. Уголовно-правовое обеспечение охраны интеллектуальной собственности: дис. ... канд. юрид. наук. М., 2013. C. 21-26. 209 c.

51. Титов С.Н. Указанная работа С. 21. 209 с.

52. Хейфец И.Я. Авторское право. 1931. С. 4.

53. Энциклопедия государства и права. Т. 1. С. 47. «Авторское право», и др. авторы.

\section{References (transliterated):}

1. Alekseenko N.N. Ugolovno-pravovaya i kriminologicheskaya kharakteristika prestuplenii v sfere registratsii nezakonnykh sdelok s zemlei. Monografiya. «Yurist», 2013. 151 s.;

2. Antimonov B.S., Fleishits E.A. Avtorskoe pravo Moskva. Gosyurizdat, 1957-278 s.

3. Bondarev V.N. Ugolovno-pravovaya okhrana intellektual'noi sobstvennosti: dis. ... kand. yurid. nauk. Rostov - na-Donu, 2002. S. 24-31. $227 \mathrm{~s}$.

4. Venediktov Yu.S. Problemy firmennykh naimenovanii yuridicheskikh lits v istoriko-pravovom kontekste. Yuridicheskii mir, 2011, № 11.;

5. Gavrilov K.M. Chto sleduet iz Postanovleniya Pravitel’stva RF ot 11.12.2012 № 1281 «Patenty i litsenzii», 2013, № 4.;

6. Dem'yanenko E.V. Ugolovnaya otvetstvennost' za nezakonnoe ispol'zovanie tovarnogo znaka: dis. ... kand. yurid. nauk. Rostov na Donu, 2003. S. 20-34.216 s.

7. E. Lozman Ob avtorskom prave. Ezhenedel'nik Sovetskoi yustitsii. 1923. № 1

8. Zhizhilenko A.A. Prestupleniya protiv imushchestva i isklyuchitel'nykh prav. L., 1928. S. 58.; 
DOI: $10.7256 / 1811-9018.2015 .8 .15784$

При цитировании этой статьи сноска на доі обязательна

\section{Право и политика $8(188) \cdot 2015$}

9. Zdravomyslov B.V. Ugolovno-pravovaya okhrana prav avtora i izobretatelya v SSSR// VYuZI. 1957.

10. Zaimovskii S.G. Avtorskoe pravo. Iz-nie 2. M., 1914. S. 4. 124 s.

11. Kondrashina V.A. Ugolovnaya otvetstvennost' za nezakonnoe ispol'zovanie tovarnogo znaka po zakonodatel'stvu Rossii i zarubezhnykh stran: dis. ... kand. yurid. nauk. Kazan', 2004. S. 149-158. 229 s.

12. Koretskii V.I. Avtorskie pravootnosheniya v SSSR. Stalinabad. 1959. S. 34-35.

13. Kotenko E.S. «Avtorskie prava na mul'timediinyi produkt: Monografiya» «Prospekt», 2013.;

14. Lepina T.N. Ugolovno-pravovaya okhrana intellektual'noi sobstvennosti: diss. ... kand. yurid. nauk. Kursk, 2014. S. 51-58. 235 s.

15. Lepina T.N. Ukazannaya rabota. S. 54. $235 \mathrm{~s}$.

16. Lepina T.N. Ukazannaya rabota. S. 53.

17. Pisenko K.A., Badmaev B.G., Kazaryan K.V. Antimonopol'noe (konkurentnoe) pravo. Podgotovleno dlya sistemy Konsul'tantPlyus, 2014.;

18. Pisenko K.A., Badmaev B.G., Kazaryan K.V. Ukazannaya rabota. S. 34.;

19. Raevich S.I. Intellektual'nye prava. 1926. S. 30 i 34 (snoska).

20. Sudarikov S.A. «Pravo intellektual'noi sobstvennosti: Uchebnik» «Prospekt», 2010;

21. Sitdikov R.I. Obespechenie chastnykh, obshchestvennykh i publichnykh interesov avtorskim pravom. «Statut» 2013.;

22. Sitdikova R.I. Obespechenie chastnykh, obshchestvennykh i publichnykh interesov avtorskim pravom. «Statut», 2013.;

23. Titov S.N. Ugolovno-pravovoe obespechenie okhrany intellektual'noi sobstvennosti: dis. ... kand. yurid. nauk. M., 2013. S. 2126. 209 s.

24. Titov S.N. Ukazannaya rabota S. 21. 209 s.

25. Kheifets I.Ya. Avtorskoe pravo. 1931. S. 4. 